\title{
Hubungan lingkar pinggang dengan frekuensi napas pada guru SMP Kristen Eben Haezar 1, 2, dan SMA Kristen Eben Haezar Manado
}

\author{
${ }^{1}$ Jessica G. Mogi \\ ${ }^{2}$ Herlina I. S. Wungouw \\ ${ }^{2}$ Hedison Polii
}

\author{
${ }^{1}$ Kandidat Skripsi Fakultas Kedokteran Universitas Sam Ratulangi Manaado \\ ${ }^{2}$ Departemen Fisiologi Fakultas Kedokteran Universitas Sam Ratulangi Manado \\ Email: mogijessica@gmail.com
}

\begin{abstract}
Waist circumference is a simple method of measuring abdominal fat, which encompasses visceral and subcutaneous fat. Excessive abdominal fat in people with large waist circumference can compress the chest wall and diaphragm mechanically causing an inability of the lungs to expand optimally, which results in shallow and rapid breathing pattern. Teachers are among the high-risk groups to experience an increase in the waist circumference due to the sedentary work pattern. This was an observational study with a cross-sectional design. This study was aimed to obtain the correlation between waist circumference and respiratory rate in teachers. The results showed that there were 84 teachers of Eben Haezar Christian Junior High School 1, 2, and Eben Haezar Christian Senior High School Manado as subjects. Measurements of waist circumference and respiratry rate were performed on all subjects. It was found that the mean waist circumference of female teachers was $89.04 \mathrm{~cm}$ meanwhile of male teachers was $92.31 \mathrm{~cm}$. The mean respiratory rate was 21 breaths per minute. The Pearson Bivariate Correlation statistic test showed that there was a significant positive moderate correlation between waist circumference and respiratory rate $(r=0.493 ; \mathrm{p}<0.05)$.
\end{abstract}

Keywords: waist circumference, respiratory rate, teachers

\begin{abstract}
Abstrak: Lingkar pinggang merupakan suatu metode sederhana yang digunakan untuk mengukur lemak di bagian abdomen, meliputi lemak viseral dan lemak subkutan. Lemak abdominal yang berlebihan menekan dinding dada dan diafragma sehingga paru-paru tidak dapat mengembang secara optimal, menyebabkan pernapasan yang cepat dan dangkal. Guru merupakan kelompok yang berisiko mengalami peningkatan ukuran lingkar pinggang dikarenakan pola pekerjaan yang sedenter. Penelitian ini dilakukan untuk melihat hubungan antara lingkar pinggang dan frekuensi napas pada guru-guru. Jenis penelitian ialah observasional dengan desain potong lintang. Terdapat 84 subjek terdiri dari guru-guru yang mengajar di SMP Kristen Eben Haezar 1, 2, dan SMA Kristen Eben Haezar Manado. Pengukuran lingkar pinggang dan frekuensi pernapasan dilakukan secara langsung. Hasil penelitian mendapatkan rerata lingkar pinggang pada guru wanita ialah $89,04 \mathrm{~cm}$ dan pada guru pria $92,31 \mathrm{~cm}$, dengan rerata frekuensi napas 21 kali per menit. Analisis statistik menggunakan uji korelasi Pearson bivariat menunjukkan bahwa ukuran lingkar pinggang memiliki korelasi positif yang bermakna dan cukup kuat dengan frekuensi napas $(r=0,493$; $\mathrm{p}<0,05)$.
\end{abstract}

Kata kunci: lingkar pinggang, frekuensi napas, guru

Obesitas dan kelebihan berat badan merupakan masalah kesehatan yang umum didapati dalam masyarakat di Indonesia. Pada tahun 2007 , terdapat $18,8 \%$ populasi 
Indonesia dengan obesitas sentral. ${ }^{1}$ Pada tahun 2013, jumlahnya telah meningkat mencapai $26,6 \%$ populasi. Pada tahun 2007, provinsi dengan jumlah penduduk yang mengalami obesitas sentral terbanyak adalah Sulawesi Utara, yakni mencapai $31,5 \%{ }^{1}$

Dalam memperoleh data ini, salah satu cara yang digunakan adalah dengan mengukur lingkar pinggang. Lingkar pinggang digunakan untuk mendefinisikan risiko terkait kelebihan lemak di daerah abdomen. Kelebihan lemak di daerah abdomen ini meliputi lemak viseral dan lemak subkutan. ${ }^{2}$ Lingkar pinggang juga merupakan cara yang sederhana dan efektif dalam mengukur obesitas sentral atau abdominal dan merupakan indikator utama dari National Cholesterol Education Program Adult Treatment Panel III (NCEP ATP III) dan kriteria International Diabetes Federation untuk definisi dan diagnosis sindrom metabolik., ${ }^{2,3}$

Obesitas merupakan faktor risiko dari berbagai masalah metabolik dan penyakitpenyakit degeneratif. Kesulitan bernapas juga merupakan salah satu masalah yang sering timbul pada orang dengan kelebihan berat badan. Kesulitan bernapas ini sering timbul meskipun orang tersebut tidak memiliki kelainan paru tertentu. ${ }^{4}$

Frekuensi napas merupakan tanda vital yang paling jarang diukur, ${ }^{5}$ padahal frekuensi napas dapat menunjukkan tanda bahwa telah terjadi hiperkarbia dan hipoksia. Frekuensi napas juga merupakan indikator yang penting untuk kerusakan parah dari banyak sistem tubuh, bukan hanya sistem pernapasan, dan oleh karena itu merupakan prediktor kunci dari hipoksia, asidosis, maupun penyakit parah lainnya. ${ }^{5}$

Littleton $^{2}$ menyatakan bahwa pada orang dengan kelebihan berat badan, biasanya akan terlihat pola napas yang cepat dan dangkal. Pola distribusi lemak di bagian perut juga berpengaruh lebih banyak terhadap frekuensi napas dibandingkan dengan indeks massa tubuh (IMT). ${ }^{2}$

Orang dewasa menghabiskan lebih dari setengah hari bekerja. Pekerjaan mengharuskan orang-orang dewasa bekerja dengan aktivitas sedenter untuk waktu yang lama. Perilaku sedenter ini dapat memengaruhi kesehatan mereka, meningkatkan obesitas, hipertensi, dan menyebabkan gangguan lemak darah. ${ }^{6}$

Guru memiliki pekerjaan berat yang meliputi mengajar, menjadi mentor untuk murid-muridnya, dan menjadi konselor. Di luar itu, guru masih harus melakukan pekerjaan administratif lain yang masih berhubungan dengan sekolah, seperti memeriksa pekerjaan rumah murid, atau menyiapkan materi untuk kegiatan belajarmengajar selanjutnya. Jam kerja yang panjang ini dapat mengurangi waktu luang guru-guru sehingga mereka tidak bisa berolahraga. $^{7}$ Untuk bisa menyempatkan waktu agar dapat berolahraga, seorang pekerja harus bekerja selama 20-39 jam per minggu. ${ }^{8}$

Guru-guru SMP dan SMA Kristen Eben Haezar harus mengajar selama 45 jam per minggu, di luar kelas ekstra untuk persiapan Ujian Nasional dan ekstrakurikuler, sehingga guru-guru ini memiliki risiko tinggi mengalami kenaikan berat badan dan peningkatan ukuran lingkar pinggang yang dapat menyebabkan abnormalitas frekuensi napas.

Penelitian ini bertujuan untuk mengetahui adanya hubungan antara lingkar pinggang dan frekuensi napas pada guru-guru SMP Kristen Eben Haezar 1, 2, dan SMA Kristen Eben Haezar Manado.

\section{METODE PENELITIAN}

Jenis penelitian ini ialah observasional analitik dengan metode survei dan desain potong lintang. Penelitian dilakukan pada bulan September sampai Desember 2016 di SMP Kristen Eben Haezar 1, 2, dan SMA Kristen Eben Haezar Manado. Populasi penelitian ialah semua guru-guru yang mengajar di sekolah-sekolah tersebut, berjumlah 116 orang. Perhitungan besar sampel menggunakan rumus Snedecor dan Cochran mendapatkan bahwa sampel minimal ialah 54 orang. Terdapat 84 orang guru yang memenuhi kriteria inklusi dan bersedia berpartisipasi dalam penelitian. 
Variabel yang diteliti ialah lingkar pinggang dan frekuensi napas. Pemeriksaan ini dilakukan dengan mengukur lingkar pinggang responden secara langsung menggunakan pita ukur yang dilingkarkan di bagian tengah antara spina iliaka dan arkus kosta. Frekuensi napas diukur tanpa diketahui responden saat tekanan darahnya diukur oleh rekan peneliti lain. Data hasil pengukuran dikelompokkan dalam bentuk tabel dan diolah secara statistik menggunakan analisis Pearson bivariat.

\section{HASIL PENELITIAN}

Penelitian yang dilaksanakan di UKS SMA Kristen Eben Haezar Manado. Sebelum penelitian dilakukan 116 informed consent diberikan pada kepala sekolah masing-masing sekolah. Sejumlah 84 orang guru-guru mengembalikan informed consent dan berpartisipasi dalam penelitian. Subjek penelitian terdiri dari 55 orang $(65,48 \%)$ wanita dan 29 orang $(34,52 \%)$ pria.

Pengukuraan yang dilakukan ialah pengukuran antropometri, tekanan darah dalam keadaan berbaring dan frekuensi napas sekaligus.

\section{Karakteristik Subjek Penelitian}

Karakteristik subjek penelitian yang berpartisipasi dalam penelitian dibagi berdasarkan jenis kelamin (Tabel 1) dan usia (Tabel 2).

Tabel 1. Karakteristik subjek berdasarkan jenis kelamin

\begin{tabular}{ccc}
\hline Jenis kelamin & (n) & \% \\
\hline Laki-laki & 29 & 34,52 \\
Perempuan & 55 & 65,48 \\
\hline
\end{tabular}

Tabel 2. Karakteristik subjek berdasarkan usia

\begin{tabular}{cccc}
\hline $\begin{array}{c}\text { Usia } \\
\text { (tahun) }\end{array}$ & $\begin{array}{c}\text { Frekuensi } \\
(\text { n) }\end{array}$ & \% & Rerata \\
\hline $18-29$ & 26 & 30,95 & $25,92 \approx 26$ \\
$30-39$ & 18 & 21,43 & 35 \\
$40-49$ & 19 & 22,62 & $45,58 \approx 46$ \\
$50-59$ & 21 & 25 & $54,67 \approx 55$ \\
\hline
\end{tabular}

\section{Nilai Lingkar Pinggang dan Frekuensi} Napas

Nilai lingkar pinggang dan frekuensi napas dijabarkan dalam bentuk tabel sebelum dimasukkan dalam perangkat lunak untuk diolah secara statistik.

Terdapat 17 orang pria $(58,62 \%)$ dengan lingkar pinggang $>90 \mathrm{~cm}$, dan terdapat 48 orang wanita $(82,27 \%)$ dengan lingkar pinggang $>80 \mathrm{~cm}$. Pria dengan lingkar pinggang $>90 \mathrm{~cm}$ memiliki rerata ukuran lingkar pinggang 99,41 cm, sedangkan pada wanita rerata ukuran lingkar pinggang $>80 \mathrm{~cm}$ ialah $91,58 \mathrm{~cm}$. Lingkar pinggang yang besar ini dapat menjadi faktor risiko sindrom metabolik dan dapat memengaruhi pernapasan (Tabel $3)$.

Tabel 3. Data ukuran lingkar pinggang guruguru

\begin{tabular}{cccc}
\hline $\begin{array}{c}\text { Lingkar } \\
\text { pinggang }(\mathbf{c m})\end{array}$ & $\mathbf{( n )}$ & $\%$ & Rerata \\
\hline Pria & & & \\
$<90 \mathrm{~cm}$ & 12 & 41,38 & 82,58 \\
$>90 \mathrm{~cm}$ & 17 & 58,62 & 99,41 \\
$\quad$ Total : & 29 & 100 & \\
Wanita & & & \\
$<80 \mathrm{~cm}$ & 7 & 12,73 & 74,43 \\
$>80 \mathrm{~cm}$ & 48 & 82,27 & 91,58 \\
$\quad$ Total & 55 & 100 & \\
\hline
\end{tabular}

Terdapat $50 \%$ dari 84 orang populasi guru yang memiliki frekuensi napas $>20$ per menit yakni sebanyak 42 orang (Tabel 4). Peningkatan frekuensi napas disebabkan oleh kebutuhan oksigen yang bertambah.

Tabel 4. Data nilai frekuensi napas guru-guru.

\begin{tabular}{lccc}
\hline Frekuensi napas & (n) & $\boldsymbol{\%}$ & Rerata \\
\hline $12-20$ & 42 & $50 \%$ & 18,61 \\
$>20$ & 42 & $50 \%$ & 22,98 \\
\hline
\end{tabular}

\section{Analisis Statistik Hubungan Lingkar Pinggang dan Frekuensi Napas}

Sebelum dilakukan uji korelasi Pearson dilakukan uji normalitas menggunakan uji Kolmogorov-Smirnov untuk melihat apakah data tersebar secara normal atau tidak. Data dengan sebaran 
normal kemudian dianalisis menggunakan uji korelasi Pearson bivariat (Tabel 5).

Tabel 5. Hasil Interpretasi uji korelasi Pearson bivariat

\begin{tabular}{clcc}
\hline $\begin{array}{c}\text { Jumlah } \\
\text { subjek }\end{array}$ & Variabel & r & Nilai p \\
\hline 84 & $\begin{array}{c}\text { Lingkar pinggang } \\
\text { dan } \\
\text { frekuensi napas }\end{array}$ & 0,493 & 0,0005 \\
\hline
\end{tabular}

Setelah dilakukan analisis dengan uji korelasi Pearson, diperoleh nilai $r=0,493$ serta nilai $\mathrm{p}=0,0005$ yang menunjukkan bahwa hubungan lingkar pinggang dan frekuensi napas cukup kuat ${ }^{9}$ dengan pola positif, artinya semakin bertambah lingkar pinggang semakin bertambah pula frekuensi napas. Hasil uji statistik menyatakan terdapat hubungan bermakna antara lingkar pinggang dan frekuensi napas.

\section{BAHASAN}

Sebagian besar guru-guru di SMP dan SMA Kristen Eben Haezar memiliki lingkar pinggang yang besar, $87,27 \%$ guruguru wanita memiliki lingkar pinggang $>80$ $\mathrm{cm}$ dan $58,62 \%$ guru-guru pria memiliki lingkar pinggang $>90 \mathrm{~cm}$. Penemuan ini relevan dengan sumber yang menyatakan bahwa guru-guru diperhadapkan dengan kelebihan berat badan dan risiko-risiko kardiovaskular dikarenakan kurangnya aktivitas fisik. ${ }^{7,8}$

Dari populasi 55 orang guru wanita, hampir semuanya memiliki lingkar pinggang $>80 \mathrm{~cm}$. Ditemukan bahwa, $100 \%$ dari guru-guru berusia di atas 45 tahun, yaitu usia memasuki masa perimenopause dan menopause ${ }^{10}$ memiliki lingkar pinggang $>80 \mathrm{~cm}$, sedangkan hanya $71,8 \%$ dari guru-guru di bawah 45 tahun yang memiliki lingkar pinggang $>80 \mathrm{~cm}$. Hal ini mungkin disebabkan oleh pengaruh dari hormon estrogen yang mulai menurun pada wanita berusia di atas 45 tahun. Penurunan ini juga disertai perubahanperubahan lain seperti penurunan massa otot dan peningkatan lemak, sehingga metabolism kalori menjadi kurang efisien.
Perubahan-perubahan ini menunjukkan penyebab wanita usia menopause memiliki kenaikan berat badan dan dengan demikian juga kenaikan ukuran lingkar pinggang. ${ }^{11}$

Ditemukan dalam penelitian ini bahwa lingkar pinggang dan frekuensi napas memiliki hubungan positif yang cukup kuat. Bila ukuran lingkar pinggang meningkat, maka frekuensi napas juga akan meningkat. Hasil penemuan ini membuktikan bahwa terdapat hubungan di antara lingkar pinggang dan frekuensi napas.

Hubungan lingkar pinggang dan faal paru seseorang telah dilaporkan dalam banyak penelitian. Parameswaran et al. ${ }^{12}$ mendeskripsikan orang yang memiliki kelebihan berat badan cenderung memiliki pola napas yang cepat dan dangkal. Saat berada dalam keadaan normal manusia menggunakan oksigen yang sedikit untuk bernapas. Pernapasan pada umumnya memerlukan tenaga banyak hanya untuk inspirasi sementara ekspirasi bersifat pasif, terjadi dengan sendirinya karena sifat rekoil elastik dari paru-paru. Untuk melakukan inspirasi, sistem respirasi harus bekerja untuk mengembangkan paru-paru melawan kekuatan elastisitas paru-paru dan dinding dada, disebut elastic work atau compliance work; melampaui viskositas dari paru-paru dan struktur dinding dada, disebut tissue resistance work; dan untuk melampaui resistensi jalan napas agar dapat menggerakkan udara ke dalam paru-paru, disebut airway resistance work. ${ }^{13}$

Orang dengan kelebihan berat badan memerlukan lebih banyak tenaga dan konsumsi oksigen untuk menggunakan otot-otot pernapasannya, ${ }^{14}$ sehingga dengan meningkatkan frekuensi napas mereka bisa mengkompensasi volume Tidal yang rendah, karena inspirasi untuk mendapatkan volume Tidal yang cukup dinilai lebih sulit dan membutuhkan banyak energi. ${ }^{12}$ Konsumsi oksigen untuk bernapas ternyata meningkat secara parabolik bersama-sama dengan meningkatnya frekuensi napas, sehingga orang-orang yang memiliki kelebihan berat badan sering memberikan hasil yang buruk pada uji fungsi-fungsi pernapasan seperti pada spirometri. ${ }^{2,12}$ 
Littleton dalam penelitiannya ${ }^{2}$ menuliskan bahwa setidaknya 4 studi, yakni studi dari Burki NK, et al., Sampson MG, et al., Pankow W, et al., dan Chlif M, et al. yang menuliskan bahwa pada orang dengan obesitas memiliki rerata frekuensi napas sebanyak 15,3-21 napas per menit dan subjek normal memiliki rerata frekuensi napas yang berkisar dari 10-12 napas per menit.

Guru-guru yang diperiksa frekuensi napasnya pada keadaan berbaring menyebabkan massa dalam abdomen mengurangi kompliansi dinding dada pada keadaan supinasi, sesuai yang dikutip oleh Littleton dari Naimarck dan Cherniak pada tahun $1960 .^{2}$ Sharp et al. juga pada tahun 1964 menuliskan pada penelitian mereka bahwa pada posisi supinasi, lemak abdomen akan berperan sebagai suatu massa yang menekan dinding dada, sehingga kompliansi dinding dada yang berkurang merupakan suatu hal yang relevan pada pasien dengan lingkar pinggang besar. ${ }^{2}$ Massa tubuh yang berlebih pada kelebihan berat badan dapat bertindak sebagai beban ambang untuk inspirasi, seperti pada orang normal yang memiliki beban di atas dadanya, sehingga orang tersebut sulit mengembangkan paru secara maksimal. Ketika dinding paru tidak dapat berkembang secara maksimal, volume tidal yang masuk ke dalam paru akan berkurang dan sebagai kompensasi, frekuensi napas pun akan bertambah. ${ }^{12}$ Setelah beban ini diangkat, dinding dada dapat berfungsi seperti semula. ${ }^{2}$

Lean et al pada tahun 1998 meneliti kualitas hidup dan kesehatan orang-orang dengan lingkar pinggang besar di Maastricht, Amsterdam, dan Doetinchem, Belanda. Lingkar pinggang diukur berdasarkan tingkatan, yakni pada pria: kurang dari tingkat $1<94,0 \mathrm{~cm}$; tingkat $1-2$ 94,0-101,9 cm; di atas tingkat $2 \geq 102,0$ $\mathrm{cm}$, sedangkan pada wanita kurang dari tingkat $1<80,0 \mathrm{~cm}$; tingkat 1-2 80,0-87,9 $\mathrm{cm}$; lebih dari tingkat $2 \geq 88,0 \mathrm{~cm}$. Lean et al. menemukan bahwa terutama yang memiliki lingkar pinggang di atas tingkat 2, memiliki napas yang pendek dan berhubungan secara bermakna dengan "napas terengah-engah saat berjalan menaiki tangga atau tanjakan". ${ }^{15}$

Parameswaran $^{12}$ menuliskan bahwa Sahebjami dan Gartside pada tahun 1996 telah menemukan bahwa secara spesifik subjek-subjek ini juga mengalami penurunan nilai FEV1, FVC, dan laju aliran maksimal inspirasi. Chen $\mathrm{Y}$ et al. $^{16}$ menemukan bahwa lingkar pinggang berhubungan secara negatif dengan FVC dan $\mathrm{FEV}_{1}$, dan hubungannya konsisten pada subjek-subjek dengan perbedaan jenis kelamin, umur, dan kategori IMT. Perhitungan rerata menunjukkan bahwa peningkatan lingkar pinggang sebanyak 1 $\mathrm{cm}$ berhubungan dengan pengurangan 13 $\mathrm{ml} \mathrm{FVC}$ dan pengurangan $11 \mathrm{ml} \mathrm{FEV}_{1}$. Temuan ini konsisten pada subjek-subjek dengan berat badan normal, berat badan berlebih, dan obesitas. Di Inggris, Chen R et al. ${ }^{17}$ menganalisis hubungan lingkar pinggang dan fungsi paru-paru pada sampel pria dan wanita. Para peneliti ini menemukan hubungan negatif antara lingkar pinggang dan fungsi paru-paru.

Sebanyak 547 referensi dipilih oleh Wehrmeister et al. ${ }^{18}$ untuk diteliti dengan metode meta-analisis. Kriteria inklusi ditetapkan dan didapatkan 10 referensi yang diteliti; 7 di antaranya menggunakan metode potong lintang. Studi meta-analisis ini menemukan bahwa peningkatan ukuran lingkar pinggang menyebabkan berkurangnya parameter fungsi paru-paru, seperti $\mathrm{FEV}_{1}$ dan FVC pada orang-orang di atas 18 tahun.

Kelebihan utama dalam penelitian ini ialah metode survei yang digunakan. Metode ini membuat semua guru yang masuk dalam kriteria inklusi dan bersedia berpartisipasi dalam penelitian dapat diambil datanya, sehingga meningkatkan peluang generalisasi yang lebih baik dalam penerapan penelitian. Data-data yang didapatkan tidak terbatas pada individuindividu dengan lingkar pinggang berlebih saja, menghasilkan analisis statistik korelasi yang lebih dinamis dan objektif.

Penggunaan lingkar pinggang dan frekuensi napas sebagai variabel juga 
merupakan kelebihan, dikarenakan dengan metode-metode pengukuran yang sederhana ini telah terbukti efektivitasnya. Waktu yang tidak lama dalam mengukur dan metode yang tidak invasif membuat subjek dapat menunggu gilirannya sehingga mengurangi kemungkinan subjek mengundurkan diri saat penelitian dilaksanakan. Lingkar pinggang merupakan pengukuran yang lebih konvensional dari indikator obesitas sentral lainnya, tidak dipengaruhi oleh jenis kelamin seperti rasio pinggang dan pinggul, sederhana, dan prosedurnya dimengerti oleh subjek.

Desain potong lintang dalam penelitian ini merupakan suatu keterbatasan. Karena dilaksanakan pada satu waktu penelitian saja, penelitian ini tidak dapat mendeteksi penyebab sebelumnya yang menyebabkan terjadi peningkatan frekuensi pernapasan. Pengukuran telah dilakukan tanpa subjek menyadari untuk mencapai objektivitas, namun faktor-faktor sebelum penelitian tidak dapat diketahui, seperti jarak yang harus ditempuh guru-guru sebelum menjalani pengukuran, dikarenakan beberapa guru datang ke UKS yang terletak di lantai 1 gedung tengah SMA Kristen Eben Haezar harus melalui jarak yang jauh untuk mencapai lokasi pengukuran. Hal ini menyebabkan guru-guru dengan lingkar pinggang yang besar harus mengeluarkan upaya lebih untuk bernapas, menghasilkan kemungkinan peningkatan frekuensi napas meski signifikansi peningkatan belum diketahui.

Lingkar pinggang sebagai pengukuran yang baik juga memiliki keterbatasan, yakni tidak dapat memisahkan kontribusi massa intraabdominal terhadap perubahan ukuran lingkar pinggang ${ }^{16}$ serta terdapat variasi lemak abdominal pada orang-orang dengan berbagai ras dan etnisitas meskipun orang-orang tersebut memiliki ukuran lingkar pinggang dan IMT yang sama. ${ }^{19}$

Penelitian kohort juga berguna untuk mengetahui kebiasaan bernapas dan kecemasan atau riwayat penyakit keluarga dan atopi masa kecil untuk mengetahui pengaruh terhadap pola napas, bukan semata-mata disebabkan efek mekanik dari penekanan massa abdomen yang besar; maupun untuk mengetahui apakah lingkar pinggang yang besar ini menghasilkan sitokin-sitokin inflamasi yang menyebabkan penyempitan jalan napas dan mempengaruhi fungsi paru secara tidak langsung. ${ }^{20}$ Perlu juga dilakukan wawancara mengenai subjek dengan lebih baik, misalnya mengenai tempat tinggal dan kehidupan keluarga, agar dapat mengetahui bagaimana ukuran lingkar pinggang subjek dipengaruhi sedemikian rupa oleh faktor-faktor tersebut, seperti perceraian atau tinggal menyendiri. ${ }^{21}$

Seseorang dengan lingkar pinggang kecil juga dapat bernapas dengan cepat bila ia memiliki masalah kecemasan. ${ }^{22}$ Faktorfaktor ini tentu akan mempengaruhi keluaran dari jumlah napas per menitnya, serta dapat berkontribusi dalam menciptakan outlier atau data yang menyimpang pada diagram tebar. Outlier ini dapat mempengaruhi signifikansi hubungan statistik yang dihasilkan ${ }^{23}$ dan bila dihilangkan atau tidak terjadi dalam pengambilan data di satu waktu saja sesuai dengan prinsip potong lintang penelitian ini, mungkin saja dapat meningkatkan kekuatan hubungan dari $\mathrm{r}=0,493$ menjadi $\mathrm{r}=0,50$ yang menandakan hubungan kuat.

Pencarian variabel atau indikator lain dapat dilakukan pada penelitian-penelitian di masa depan dengan rancangan penelitian longitudinal/kohort agar dapat menjelaskan hubungan kausal yang lebih mendalam dibandingkan korelasi. Dengan adanya variabel-variabel lain seperti aktivitas fisik atau penyakit yang mendasari, maka akan dapat dibuat pembahasan yang lebih mendalam.

Secara klinis, penelitian ini menunjukkan bahwa bila ukuran lingkar pinggang meningkat maka frekuensi napas juga akan meningkat (hubungan positif). Peningkatan frekuensi napas pada orang dengan ukuran lingkar pinggang berlebih merupakan indikator awal dan gambaran tentang kondisi sistem respirasi yang dimiliki para subjek. Bila terus dibiarkan, obesitas sentral dapat menyebabkan gangguan pernapasan yang lebih 
serius. ${ }^{12,20,24-27}$ Lingkar pinggang yang besar juga dapat menurunkan berbagai fungsi paru sehingga harus digunakan sebagai salah satu aspek yang akan diukur pada pemeriksaan fungsi paru. ${ }^{14}$

\section{SIMPULAN}

Sebanyak 58,62\% guru laki-laki memiliki lingkar pinggang di atas $90 \mathrm{~cm}$, dan sebanyak $82,27 \%$ guru-guru wanita memiliki lingkar pinggang di atas $80 \mathrm{~cm}$. Frekuensi napas di atas 20 didapatkan pada $50 \%$ dari populasi. Hasil penelitian ini menunjukkan bahwa terdapat hubungan bermakna yang cukup kuat antara ukuran lingkar pinggang dan frekuensi napas $(\mathrm{r}=$ 0,493 dan $p=0,0005$ ).

\section{SARAN}

Perlu dilakukan penelitian lebih lanjut dengan melibatkan variabel-variabel lain yang bisa menjadi faktor risiko peningkatan ukuran lingkar pinggang atau memengaruhi keluaran frekuensi napas, seperti aktivitas fisik dan kondisi psikologis.

Perlu dipertimbangkan untuk menggunakan cara pengukuran lingkar pinggang dan lemak abdominal lain seperti Magnetic Resonance Imaging agar dapat melihat apakah ada massa intraabdominal atau penyebab lain yang menyebabkan peningkatan ukuran lingkar pinggang.

Upaya promotif seperti penyuluhan pada guru-guru juga perlu dilakukan agar dapat meningkatkan kesadaran mengenai pentingnya menjaga ukuran lingkar pinggang tetap ideal.

\section{DAFTAR PUSTAKA}

1. Badan Penelitian dan Pengembangan Kesehatan Kementerian Kesehatan RI. Penyajian Pokok-Pokok Hasil Riset Kesehatan Dasar 2013 [Internet]. 2013 [cited 30 September 2016]. Available from: URL: http://www.pusdatin.kemkes.go.id/res ources/download/general/pokok2\%20 hasil\%20riskesdas\%202013.pdf

2. Littleton SW. Impact of obesity on respiratory function. Respirology. 2012;17:43-9.

3. Després JP, Lemieux I, Bergeron J,
Pibarot P, Mathieu P, Larose E, et al. Abdominal obesity and the metabolic syndrome: contribution to global cardiometabolic risk. Arterioscler Thromb Vasc Biol. 2008; 28:1039-49.

4. Salome CM, King GG, Berend N. Physiology of obesity and effects on lung function. $\mathrm{J}$ Appl Phyisol. 2010;108:206-11.

5. Cretikos MA, Bellomo R, Hillman K, Chen J, Finfer $\mathbf{S}$, dan Flabouris A. Respiratory rate: the neglected vital sign. MJA. 2008;188(11):657-9.

6. Li C, Ford ES, McGuire LC, Mokdad AH. Increasing trends in waist circumference and abdominal obesity among U.S. adults. Obesity. 2007;15(1):216-24.

7. Retamal MEC. Teachers workplace: physical activity and sedentary behavior [disertasi]. New Zealand: Auckland University of Technology; 2013.

8. Cheung PYP, Chow BC. Association of school teachers occupational and daily physical activity level in Hong Kong. Int $\mathbf{J}$ Sport Health Sci. 2012;10:23-9.

9. Hastono SP. Basic data analysis for health research modul kedua: analisis univariat analisis bivariat. Jakarta: Fakultas Kesehatan Masyarakat Universitas Indonesia, 2006; P. 67.

10. Sherwood L. Sistem reproduksi. Fisiologi manusia dari sel ke system (6th ed). Jakarta: EGC, 2011; p. 846.

11. Cherney K. Weight gain and menopause. Healthline Media [Internet]. Direvisi pada 2016, Feb [cited 9 Desember 2016]. Available from: URL: http://www.healthline.com/health/me nopause/weightgain\&ei=OyWCpVSF\&lc=idID\& $s=1 \& \mathrm{~m}=789$

12. Parameswaran K, Todd DC, Soth M. Altered respiratory physiology in obesity. Can Respir J. 2006;13(4): 203-10.

13. Guyton AC, Hall JE. Textbook of medical physiology (11th ed). Philadelphia: Elsevier Saunders, 2006; p 475-7.

14. Sood A. Altered resting and exercise respiratory physiology in obesity. Clin Chest Med. 2009;30:445-54. 
15. Lean ME, Han TS, Seidell JC. Impairment of health and quality of life in people with large waist circumference. Lancet. 1998;351(9106):853-6.

16. Chen Y, Rennie D, Cormier YF, Dosman J. Waist circumference is associated with pulmonary function in normalweight, overweight, and obese subjects. Am J Clin Nutr. 2007;85:359.

17. Chen R, Tunstall-Pedoe H, Bolton-Smith C, et al. Association of dietary antioxidants and waist circumference with pulmonary function and airway obstruction. Am J Epidemiol. 2001;153:157-63.

18. Wehrmeister FC, Menezes AMB, Muniz LC, Martinez-Mesa J, Domingues MR, Horta BL. Waist circumference and pulmonary function: a systematic review and meta-analysis. Systematic Reviews. 2012;1(55):1-9.

19. Carroll JF, Chiapa AL, Rodriquez M, Phelps DR, Cardarelli KM, Vishwanatha JK, et al. Visceral fat, waist circumference, and BMI: impact of race/ethnicity. Obesity. 2008;16(3):600-7.

20. Capelo AV, de Fonseca VM, Peixoto MVM, de Carvalho SR, Guerino LG. Central obesity and other factors associated with uncontrolled asthma in women. Allergy, Asthma \& Clinical Immunology. 2015;11:12

21. Choi BK, Schnall PL, Yang H, Dobson $M$, Landsbergis $\mathbf{P}$, Israel $\mathbf{L}$, et al. Sedentary work, low physical job demand, and obesity in US workers. American Journal of Industrial Medicine [Internet]. 2010 Jul. Wiley
Online Library, DOI: 10.1002/ajim.20886.

22. Yuan G, Drost NA, McIvor NA. Respiratory and breathing pattern. MUMJ. 2013;10(1):23-5

23. Williams R. Outliers. University of Notre Dame Scholarly Publications [Internet]. Direvisi pada 2016 Apr [cited 26 Oktober 2016]. Available from:https://www.google.co.id/url?sa $=\mathrm{t} \&$ source $=$ web $\& \mathrm{rct}=\mathrm{j} \&$ url $=\mathrm{https}: / / \mathrm{w}$ ww3nd.edu/ rwilliam/stats2/124.pdf\& ved=0ahUKEwiLzfqxzoLQAhVEKY 8KHSgDB1gQFggZMAA\&usg=AF QjCNG1Q1cCEP1_mqLTcLtqkjpAq R680g\&sig2=UsimwVyTKEEfNMqagXeDW

24. Brumpton B, Langhammer A, Romundstad P, Chen Y, Mai XM. General and abdominal obesity and incident asthma in adults: the HUNT study. Eur Respir J. 2013;41:323-9).

25. Pillar G, Shedaheh N. Abdominal fat and sleep apnea: the chicken or the egg? Diabetes Care. 2008;31(suppl 2):3039

26. Schwartz AR, Patil SP, Laffan .AM, Polotsky V, Schneider $H$, and Smith PL. Obesity and obstructive sleep apnea: pathogenic mechanisms and therapeutic approaches. Proc Am Thorac Soc. 2008;5:185-92.

27. Kryger MH. Sleep apnea: from the needles of Dionysius to continuous positive airway pressure. Arch Intern Med [Internet]. 1983 Des [cited 18 Agustus 2016];143:2301-03. Available from:URL: http://archinte.jamanetwork.com/ by a University of Pittsburgh User on 06/03/2015 